\title{
Intake, nutrient apparent digestibility and ruminal constituents of sheep fed diets with canola, sunflower or castor oils ${ }^{1}$
}

\section{Michelle de Oliveira Maia², Ivanete Susin ${ }^{3}$, Evandro Maia Ferreira², Cristine Paduan Nolli², Renato Shinkai Gentil ${ }^{2}$, Alexandre Vaz Pires ${ }^{3}$, Gerson Barreto Mourão ${ }^{3}$}

\author{
${ }^{1}$ Financially supported by FAPESP (Fundação de Amparo à Pesquisa do Estado de São Paulo). \\ 2 Programa de Pós-Graduação em Ciência Animal e Pastagem - ESALQ/USP, Piracicaba/SP, Brazil. \\ ${ }^{3}$ Departamento de Zootecnia - ESALQ/USP, Piracicaba/SP, Brazil.
}

\begin{abstract}
The objective in this experiment was to determine the effects of feeding diets with canola, sunflower or castor oils on intake, nutrient apparent digestibility and ruminal constituents of crossbred Dorper $\times$ Santa Inês sheep. Four rumen-cannulated animals of $90.2 \pm 11.4 \mathrm{~kg}$ average body weight were assigned to a $4 \times 4$ latin square. Animals remained individually in cages for the metabolism assay and were fed diets containing roughage at $500 \mathrm{~g} / \mathrm{kg}$ and concentrate based on ground corn and soybean meal also at $500 \mathrm{~g} / \mathrm{kg}$. No oil was added to the control diet, whereas the others had canola, sunflower or castor oils at $30 \mathrm{~g} / \mathrm{kg}$ (DM basis). There was no difference for the intake of DM and nutrients, except for ether extract, which was greater when animals received oil. The digestibility coefficients of dry matter, organic matter, crude protein, nonfiber carbohydrates and neutral detergent fiber were not changed; however, the addition of oil increased the ether extract digestibility. The values of total digestible nutrients (TDN, g/kg of DM), digestible energy (DE, Mcal $/ \mathrm{kg}$ of DM), TDN intake and DE intake also did not change with the addition of lipids. Concerning the ruminal constituents, the addition of vegetable oils reduced the concentrations of acetate, butyrate and total short-chain fatty acids. Adding canola, sunflower or castor oils at $30 \mathrm{~g} / \mathrm{kg}$ in diets with $500 \mathrm{~g}$ roughage $/ \mathrm{kg}$ and $500 \mathrm{~g}$ concentrate $/ \mathrm{kg}$ does not impair the intake or digestibility of nutrients in sheep, although it reduces the concentration of short-chain fatty acids in the rumen.
\end{abstract}

Key Words: ammonia, lipids, metabolism, short-chain fatty acids

\section{Introduction}

Ruminant nutrition is usually composed of fatty acids predominantly unsaturated. The meat and milk of these animals, on the other hand, contain high contents of saturated fatty acids due to the high metabolic activity in the animal rumen during a process known as biohydrogenation (Shingfield \& Griinari, 2007).

Changes in diet characteristics can greatly alter ruminal metabolism and, therefore, affect the influx of nutrients that reach the duodenum. Despite these changes, in general, lipid supplementation is used to increase dietary energy density and to alter the composition of the final product.

Studies on lipid supplementation of diets have shown conflicting results, which are, in turn, a subject of contradictions. Fermentative parameters of the rumen can be modified by the addition of lipid sources to the diet (Jenkins, 1993); however, some studies have found no changes (Beauchemin et al., 2007). The extent of this change depends on the composition of the basal diet (Toral et al., 2009), as well as on the source and amount of fat added to the diet (Homem Junior et al., 2010).
According to Palmquist \& Mattos (2006), some fatty acids are toxic to ruminal microorganisms responsible for biohydrogenation, such as medium-chain fatty acids (10 to 14-atom carbon) and long-chain polyunsaturated fatty acids, which suggests that not only the length of the chain, but also the unsaturation level may affect ruminal fermentation, and consequently, nutrient intake.

In spite of having the same chain size, canola, sunflower and castor oils are composed of fatty acids of different saturation levels. In addition, ricinoleic acid, found in castor oil, has a hydroxyl in its chain, whose effect on ruminal fermentation is still not well explained.

Thus, the objective in this study was to assess nutrient intake and digestibility as well as ruminal measures of sheep fed canola, sunflower or castor oils in diets with $500 \mathrm{~g}$ of roughage $/ \mathrm{kg}$ of DM.

\section{Material and Methods}

The experiment was carried out at the Departamento de Zootecnia, Escola Superior de Agricultura "Luiz de Queiroz" (ESALQ), Universidade de São Paulo, Piracicaba, state of São Paulo, Brazil. Four rumen-cannulated crossbred 
rams (Dorper $\times$ Santa Inês) with initial body weight of $90.2 \pm 11.4 \mathrm{~kg}$ were used. Animals were placed individually in suspended metallic crates of $1.30 \times 0.55 \mathrm{~m}$, provided with a feeder, a water trough and a separate system for collecting feces and urine.

The experiment lasted 84 days and was divided into four periods of 21 days. The first 17 days of each period were used for animals to adapt to the experimental diets and on the four subsequent days, data and samples were collected to determine intake and total apparent digestibility of dry matter and nutrients.

The experimental diets were composed mainly by corn, soybean meal and good quality coastcross hay (Table 1). Corn grain was ground in a mill, characterizing coarse milling. Coastcross hay was also coarsely chopped to reduce the animal diet selection and feed waste. A control diet (no oil added) and 3 other diets containing $30 \mathrm{~g} / \mathrm{kg}$ of DM of canola, sunflower or castor oils were used. Concentrate: roughage ratio was 50:50. The percentage of ingredients as well as the chemical composition of the diets with oils was similar, given that only the lipid source was changed (Table 2).

Table 1 - Chemical composition of feeds used in the experimental $\operatorname{diets}(\mathrm{g} / \mathrm{kg}$ of $\mathrm{DM})$

\begin{tabular}{lccc}
\hline & Ground corn & Soybean meal & Coastcross hay \\
\hline Organic matter & 983 & 924 & 948 \\
Crude protein & 95 & 517 & 125 \\
Neutral detergent fiber & 215 & 294 & 776 \\
Ether extract & 40 & 14 & 12 \\
Non-fiber carbohydrates & 632 & 99 & 36 \\
\hline
\end{tabular}

Table 2 - Ingredients and chemical composition of experimental $\operatorname{diets}(\mathrm{g} / \mathrm{kg}$ of $\mathrm{DM})$

\begin{tabular}{|c|c|c|}
\hline & \multicolumn{2}{|c|}{ Diets } \\
\hline & Control $^{1}$ & Oil added ${ }^{1}$ \\
\hline \multicolumn{3}{|l|}{ Ingredients } \\
\hline Coastcross hay & 500 & 500 \\
\hline Ground corn & 388 & 351 \\
\hline Soybean meal & 84 & 91 \\
\hline $\mathrm{Oil}^{1}$ & - & 30 \\
\hline Urea & 3 & 3 \\
\hline Limestone & 6 & 6 \\
\hline Mineral premix ${ }^{2}$ & 19 & 19 \\
\hline \multicolumn{3}{|l|}{ Chemical composition } \\
\hline Dry matter & 860 & 885 \\
\hline Crude protein & 151 & 151 \\
\hline Organic matter & 961 & 961 \\
\hline Ether extract & 24 & 51 \\
\hline Neutral detergent fiber & 496 & 491 \\
\hline Non-fiber carbohydrates & 284 & 262 \\
\hline
\end{tabular}

The canola oil had a higher content $(57.4 \mathrm{~g} / 100 \mathrm{~g})$ of oleic acid (C18:1), while the sunflower and castor oils had higher concentration of linoleic $(59.8 \mathrm{~g} / 100 \mathrm{~g})$ and ricinoleic $(81.1 \mathrm{~g} / 100 \mathrm{~g})$ acids, respectively (Table 3).

The oil was weighed daily on a $5 \mathrm{~g}$ precision electronic scale and mixed to the concentrate and hay moments before feeding. Every day of collection, diets were weighed on a $5 \mathrm{~g}$ precision electronic scale and offered ad libitum at $7 \mathrm{~h} 30$ in the morning. The amount of diet offered was adjusted according to the feed intake during the adaptation period of the animals, ands no orts greater than $100 \mathrm{~g} / \mathrm{kg}$ were allowed. During four days in the collection period, at $7 \mathrm{~h} 30$ in the morning, the orts were weighed to obtain the dry matter intake (DMI) per animal and total amount of feces generated in 24 hours. A harness equipped with a bag was used for fecal collection, in order to prevent the urine from mixing with feces.

Samples of feed, orts and feces $(100 \mathrm{~g} / \mathrm{kg}$ of the total $)$ were collected during four days, forming composite samples per animal, and preserved at $-20{ }^{\circ} \mathrm{C}$ for later analyses. Samples were thawed and dried in a forced-ventilation oven $\left(55^{\circ} \mathrm{C}\right)$ for 72 hours and ground with a Wiley-type mill to pass through a $1 \mathrm{~mm}$ screen.

Determination of DM, OM and EE was conducted according to the AOAC (2000). The OM was obtained by the difference between DM and MM contents.

The NDF was determined according to Van Soest et al. (1991), with sodium sulfite and thermostable $\alpha$-amylase, using fiber analyzer Ankon $^{220}$, as described by Holden (1999). The values obtained were corrected for ash after incineration of the bags. The non-fiber carbohydrates (NFC) contents of ingredients were calculated according to Mertens (1997) and total digestible nutrients (TDN), as described by Weiss et al. (1992) based on the formulas: NFC $=100$ $(\mathrm{NDF}+\mathrm{CP}+\mathrm{EE}+\mathrm{MM})$ and $\mathrm{TDN}=\mathrm{DCP}+(\mathrm{DEE} \times 2.25)$ $+\mathrm{DNDF}+\mathrm{DNFC}$, respectively, where DCP $=$ digestible crude protein, $\mathrm{DEE}=$ digestible ether extract, DNDF = digestible neutral detergent fiber and DNFC = digestible non-fiber carbohydrates. Due to the presence of urea in the concentrates, the NFC was calculated as proposed by

Table 3 - Fatty acid composition of canola, sunflower and castor oils (g/100 g of fat)

\begin{tabular}{lccc}
\hline Fatty acid & Canola & Sunflower & Castor \\
\hline C16:0 (palmitic) & 4.4 & 6.5 & 1.3 \\
C18:0 (estearic) & 2.5 & 3.4 & 1.1 \\
C18:1 (oleic) & 57.4 & 22.9 & 3.6 \\
C18:1-OH (ricinoleic) & - & - & 81.1 \\
C18:2 (linoleic) & 17.3 & 59.8 & 5.6 \\
C18:3 $\omega-3$ (linolenic) & 5.3 & 0.6 & 0.5 \\
Others & 7.7 & 5.4 & 6.0 \\
\hline
\end{tabular}


Hall (2000): $\mathrm{NFC}=100-[(\% \mathrm{CP}-\% \mathrm{CP}$ from urea $+\%$ of urea) $+\% \mathrm{NDF}+\% \mathrm{EE}+\% \mathrm{ash}]$. The concentration of digestible energy (DE) was calculated according to Swift (1957) by the formula: DE $(\mathrm{Mcal} / \mathrm{kg})=0.04409 \times \mathrm{TDN}$ $(\mathrm{g} / \mathrm{kg})$, where $\mathrm{DE}=$ digestible energy.

The total nitrogen was quantified based on the combustion of samples in a LECO ${ }^{\circledR}$ analyzer model FP 528 at combustion temperature of $835^{\circ} \mathrm{C}$ (Wiles et al., 1998). The CP content was obtained by multiplying the total $\mathrm{N}$ content by 6.25 .

For the analysis of EE in the feces, acidified ether with acetic acid was used to remove the salts from fatty acids (Mattos \& Palmquist, 1974).

The fatty acids of oils were methylated according to Kramer et al. (1997) using $100 \mathrm{mg}$ of each oil. After, the samples were stored at $-18{ }^{\circ} \mathrm{C}$ in an amber flask containing $\mathrm{N}$ to avoid oxidation. The oil fatty acid composition was determined by gas-liquid chromatography (GLC) using an Agilent equipment (7890-A, Agilent Technologies), with flame ionization detector (7683-B, Agilent Technologies) and a $100 \mathrm{~m}$ long and $250 \mu \mathrm{m}$ inner diameter capillary fused silica column ( $\mathrm{J} \& \mathrm{~W}$ 112-88A7, Agilent Technologies) containing $0.20 \mu \mathrm{m}$ of cyanopropyl polysiloxane. Data were obtained with the software ChemStation (Agilent Tecnologies).

For oil fatty acid separation by GLC, one microliter $(\mu \mathrm{L})$ of the sample was injected with a $10 \mu \mathrm{L}$ syringe in the split system at a 50:1 ratio. Hydrogen was used as carrier gas at a flow rate of $1.0 \mathrm{~mL} / \mathrm{min}$ and nitrogen was used as make-up with the output regulated to $30 \mathrm{~mL} / \mathrm{min}$. The synthetic air output was kept at $300 \mathrm{~mL} / \mathrm{min}$ and the temperatures in the injector and detector were 250 and $255^{\circ} \mathrm{C}$, respectively.

The initial temperature in the oven was $70{ }^{\circ} \mathrm{C}$, gradually increased by $5{ }^{\circ} \mathrm{C} / \mathrm{min}$ until $100{ }^{\circ} \mathrm{C}$ and then held for 2 minutes. Afterwards, at a $10{ }^{\circ} \mathrm{C} / \mathrm{min}$ increase, the oven temperature reached $175{ }^{\circ} \mathrm{C}$ and was maintained for 40 minutes. In the third stage the temperature reached $225^{\circ} \mathrm{C}$ by a $5{ }^{\circ} \mathrm{C} / \mathrm{min}$ increase. Next, the oven temperature increased $20^{\circ} \mathrm{C} / \mathrm{min}$ until a final temperature of $245^{\circ} \mathrm{C}$. The total run time for the analyses was 87.5 minutes.

Fatty acids were identified by comparing their retention times with the fatty acid methyl standards. A mix standard Supelco $^{\circledR}$ (Sigma Aldrich) of 37 compounds and individual standards to identify fatty acids C18:1 trans-11, C18:2 cis-9, trans-11, C18:2 trans-10, cis-12 (Nu-Chek Prep, Inc.) and C18:1 - OH (Sigma Aldrich) were used.

Samples of ruminal content were obtained on the $21 \mathrm{st}$ day of each period, at a two-hour interval, starting just prior to feeding. Zero hour was considered the moment before feeding, and 2, 4, 6, 8, 10 and 12 hours, post-feeding. Rumen ammonia nitrogen $\left(\mathrm{N}-\mathrm{NH}_{3}\right)$ and short-chain fatty acids (SCFA) of the ruminal fluid were determined.

A representative sample of ruminal content of each animal was collected via cannula and squeezed through 2 layers of cheesecloth. Rumen fluid $\mathrm{pH}$ was measured immediately after sampling, by using a digital $\mathrm{pH}$ meter (DM20, Digimed, São Paulo, Brazil). The solid phase of the ruminal content that remained in the tissue, after filtering, was returned to the rumen.

After recording the $\mathrm{pH}$, two $25 \mathrm{~mL}$ aliquots of rumen fluid were stored in plastic flasks containing $1.25 \mathrm{~mL}$ of $6 \mathrm{~N}$ $\mathrm{HCl}$ and frozen at $-20{ }^{\circ} \mathrm{C}$ for further analyses of SCFA and ruminal ammonia $\left(\mathrm{N}-\mathrm{NH}_{3}\right)$.

To determine SCFA, $1.6 \mathrm{~mL}$ of thawed rumen fluid was centrifuged at $15,000 \times \mathrm{g}$, during 15 minutes at $4{ }^{\circ} \mathrm{C}$, with $0.4 \mathrm{~mL}$ of a $3: 1$ solution of metaphosphoric $25 \%$ with formic acid 98-100\% (Cottyn \& Boucque, 1968; Filipek \& Dvorak, 2009) $+0.2 \mathrm{~mL}$ of acid solution 2-methyl-buritric $100 \mathrm{mM}$ (internal standard). After centrifugation, approximately $1.2 \mathrm{~mL}$ was transferred to the chromatograph vial.

For the SCFA separation by GLC, $1 \mu \mathrm{L}$ of the sample was injected with a $10 \mu \mathrm{L}$ syringe in a split system at a 20:1 ratio with $\mathrm{H}_{2}$ flow of $31.35 \mathrm{~mL} / \mathrm{min}$ in a gas chromatograph (7890-A, Agilent Technologies) equipped with a detector (7683B, Agilent Technologies) and a capillary fused silica column DB-WAX $(30 \mathrm{~m} \times 0.25 \mathrm{~mm} \times 0.25 \mu \mathrm{m}$ of propylene glycol, Agilent Technologies). The data were obtained by software ChemStation (Agilent Tecnologies).

The injector and detector were kept at $260{ }^{\circ} \mathrm{C}$. The heating ramp of the oven was: $80{ }^{\circ} \mathrm{C}(1 \mathrm{~min}), 120{ }^{\circ} \mathrm{C}$ $\left(20^{\circ} \mathrm{C} / \mathrm{min}, 3 \mathrm{~min}\right), 205^{\circ} \mathrm{C}\left(10^{\circ} \mathrm{C} / \mathrm{min}, 2 \mathrm{~min}\right)$, and $16.5 \mathrm{~min}$ was the total run time. Hydrogen was used as carrier gas at a flow rate of $1.35 \mathrm{~mL} / \mathrm{min}$ and nitrogen was used as make-up. In the detector, flows of hydrogen, synthetic air and nitrogen (make up) were kept at 40, 400 and $40 \mathrm{~mL} / \mathrm{min}$, respectively.

The external calibration curve was made with chromatograph standards of acetic, propionic, isobutyric, butyric, isovaleric and valeric acids. The standard mixture of higher concentration (denominated "super high") contained $200 \mathrm{mM}$ of acetic acid, $54 \mathrm{mM}$ of propionic acid, $6 \mathrm{mM}$ of isobutyric acid, $45 \mathrm{mM}$ of butyric acid, $9 \mathrm{mM}$ of isovaleric acid and $9 \mathrm{mM}$ of valeric acid. The standard solutions were obtained by diluting the "super high" mixture by $1 / 2$ (high), 1/4 (medium), 1/8 (low) and 1/16 (very low). Afterwards, for the preparation of vials of standard solutions, the same amounts of a 3:1 metaphosphoric acid: formic acid solution was used in addition to the internal standard used in the preparation of samples. 
The second plastic flask of each sample was thawed for the analysis of $\mathrm{N}-\mathrm{NH}_{3}$ to be carried out by the colorimetric method described by Chaney \& Marbach (1962), adapted to microplate reader (BIO - RAD), using a filter for the absorbance of $550 \mathrm{~nm}$ (Campos et al., 2004).

The experimental design was a $4 \times 4$ latin square, with four diets, four animals and four experimental periods.

Statistical analysis was performed with PROC MIXED of SAS (Statistical Analysis System, version 9.0). For the variables related to intake and digestibility, the following model of analysis was used: $\mathrm{Y}_{\mathrm{ijk}}=\mu+\mathrm{T}_{\mathrm{i}}+\mathrm{V}_{\mathrm{j}}+\mathrm{P}_{\mathrm{k}}+\mathrm{E}_{\mathrm{ijk}}$, where: $\mathrm{Y}_{\mathrm{ijk}}=$ animal observation $\mathrm{j}$, in period $\mathrm{k}$, subjected to diet $\mathrm{i} ; \mu=$ overall constant; $\mathrm{T}_{\mathrm{i}}=$ diet effect $\mathrm{i}$, where $\mathrm{i}=1,2$, 3 and $4 ; \mathrm{V}_{\mathrm{j}}=$ animal effect $\mathrm{j}$, where $\mathrm{j}=1,2,3$ and $4 ; \mathrm{P}_{\mathrm{k}}=$ effect of period $\mathrm{k}$, where $\mathrm{k}=1,2,3$ and $4 ; \mathrm{E}_{\mathrm{ijk}}=$ random error associated with each observation of ijk.

The ruminal measures were analyzed as repeated measures, which required the choice for the most adequate covariance structure for variations of measures within the treatment for each characteristic. This choice was based on values of Akaike Index of Corrected Criterion (AICC) and the Baysean Schwarz Criterion (BIC). The characteristics and respective structures of covariance chosen for the modeling of repeated measures that best adjusted to the dataset were: auto-regressive of first order (AR1) for the ammonia variables, $\mathrm{pH}$, isobutyrate and valeric acid; variance components (VC) for the ruminal concentration of acetate and fatty acids in the SCFA; autoregressive heterogeneous of first order $(\mathrm{ARH}-1)$ for the ruminal concentration of propionate, isovaleric acid and acetate:proprionate ratio (A:P); and heterogeneous Toeplitz (TOEPH) for the concentration of butyrate.

When the effect of the treatment was significant $(\mathrm{P}<0.05)$, means were compared with the Tukey test.

\section{Results and Discussion}

Lipid supplementation to the diet of sheep did not affect $(\mathrm{P}>0.05) \mathrm{DM}$ and nutrient intakes (Table 4).

Intake reduction is usually caused by the toxicity of fatty acids to ruminal microorganisms, which is related to their detergent nature, i.e., those that are insoluble in organic solvents and in water are more toxic. These acids include fatty acids of medium chain (10 to 14 carbons) and polyunsaturated fatty acids of long chain (LCFA) (Palmquist \& Mattos, 2006).

Among the oil sources studied, canola is composed mostly of oleic acid, which, despite being a LCFA (C18), is monounsaturated, similarly to the castor oil, which is composed mostly of ricinoleic acid with only one double bond in its chain, and is, therefore, less toxic to ruminal microorganisms. The ricinoleic acid also has a hydroxyl linked to the carbon-9 that gives the castor oil unique properties, such as higher oxidative stability that is responsible for lower oil rancidity, making it an attractive alternative for ruminant nutrition (Muller, 1978). On the other hand, the sunflower oil is composed of a large quantity of polyunsaturated fatty acids containing approximately $60 \%$ of linoleic acid in their composition (Table 3).

Table 4 - Body weight $(\mathrm{BW})$, metabolic weight $\left(\mathrm{BW}^{0.75}\right)$ and nutrient intake by crossbred Dorper $\times$ Santa Inês sheep fed diets with vegetable oils

\begin{tabular}{lccccc}
\hline \multirow{2}{*}{ Variables } & \multicolumn{3}{c}{ Diets } & \multicolumn{2}{c}{ Standard error of } \\
the mean
\end{tabular}


Therefore, the lack of effects caused by the addition of vegetable oils to sheep diets is attributed to the quantity of lipid added and the composition of the basal diet. In the current study, the content of ether extract in the control diet was $24 \mathrm{~g} / \mathrm{kg}$ and in the diets containing $30 \mathrm{~g}$ of oil $/ \mathrm{kg}$ of $\mathrm{DM}$, it was $51 \mathrm{~g} / \mathrm{kg}$ of DM.

Lipid supplementation to the diet may reduce DM intake and digestibility when the EE content is higher than $70 \mathrm{~g} / \mathrm{kg}$ of DM in the diet (Palmquist \& Jenkins, 1980). In this experiment, the EE content in the diets containing oils was $51 \mathrm{~g} / \mathrm{kg}$, which probably explains why the addition of sunflower oil, which contains large amounts of polyunsaturated fatty acids, did not reduce nutrient intake.

Also, the oil addition did not affect the intake of DM, $\mathrm{CP}$ or NDF, following the same behavior of DM intake. However, the oil addition promoted higher EE intake in relation to the animals fed the control diet, which was expected, once the diets with oils were formulated with EE supplementation.

Corroborating this study, Maia et al. (2010) evaluated the addition of 30 or $50 \mathrm{~g}$ of "licuri" or castor oil $/ \mathrm{kg}$ of goat diets with $470 \mathrm{~g} / \mathrm{kg}$ of roughage and did not report reduction of DM intake and nutrients when $30 \mathrm{~g}$ of castor oil $/ \mathrm{kg}$ were offered to animals in the total diet.

Regarding apparent digestibility of DM, of organic matter, of crude protein, of non-fiber carbohydrates and the digestibility of neutral detergent fiber, values attributed to the control diet and to the diets containing oils remained similar $(\mathrm{P}>0.05)$, which suggests that the addition of these lipid sources preserved the balance of ruminal microorganisms and, therefore, showed a digestion similar to the control diet (Table 5).

Among the several factors that can affect nutrient digestibility with lipid supplementation to the diet (basal fat content of the diet, type and quantity of lipids, among others), forage content is an important item to be considered (Nörnberg et al., 2004).
In all diets analyzed, there was a good amount of fiber ( $500 \mathrm{~g}$ of hay $/ \mathrm{kg}$ of DM) in the diet, which may have contributed to these results, once the fiber content possibly competed with the binding of fatty acids to the food particles in the rumen, thus preventing interference on ruminal fiber digestion (Bateman \& Jenkins, 1998).

Maia et al. (2010) evaluated different contents (30 and $50 \mathrm{~g} / \mathrm{kg}$ of DM) of "licuri" or castor oil in diets of lactating goats with $470 \mathrm{~g}$ of hay $/ \mathrm{kg}$ of DM and did not observe changes in the apparent digestibility of DM. Similarly, Palmquist \& Griinari (2006) did not find adverse effect on ruminal fermentation with the addition of a combination of sunflower and fish oils in cattle diets with $600 \mathrm{~g}$ of fiber $/ \mathrm{kg}$ of DM.

Regarding the ether extract apparent digestibility (EEAD), there was an increase when animals received a supplement with oils, probably due to the higher ether extract intake (EEI), similar to results found by Maia et al. (2010), who also reported higher EEAD when animals were fed "licuri" or castor oil.

The TDN values $(\mathrm{g} / \mathrm{kg} \mathrm{DM})$ and $\mathrm{DE}$ content $(\mathrm{Mcal} / \mathrm{kg}$ of DM) were not affected $(\mathrm{P}>0.05)$ by the diets. The TDN values were expected to increase, given that the food energy comes from organic compounds such as $\mathrm{CP}$ and $\mathrm{EE}$ and from fiber fractions.

Although no changes were found for the intake and digestibility of DM, CP and NDF, there was an increase of EEI in animals fed oil, and, besides, the EEAD of diets containing oils was approximately $10 \%$ higher as compared with the control diet.

As no changes were observed for the values of DMI, TDN $(\mathrm{g} / \mathrm{kg} \mathrm{DM})$ and DE content (Mcal/ $\mathrm{kg}$ of DM), no difference was found for TDN intake (kg/day) and DE (Mcal/day).

The lipid supplementation showed decreased $(\mathrm{P}<0.05)$ concentrations of acetate, butyrate and total SCFA $(\mathrm{P}<0.05)$. There was an effect of feeding time on all variables analyzed; however there was no interaction between the diets and feeding time (Table 6).

Table 5 - Nutrient digestibility $(\mathrm{g} / \mathrm{g}$ of DM), intake of total digestible nutrients and digestible energy by Dorper $\times$ Santa Inês sheep fed vegetable oils

\begin{tabular}{|c|c|c|c|c|c|c|}
\hline \multirow{2}{*}{ Variable } & \multicolumn{4}{|c|}{ Diets } & \multirow{2}{*}{$\begin{array}{c}\text { Standard error of } \\
\text { the mean }\end{array}$} & \multirow{2}{*}{ P-value } \\
\hline & Control & Canola & Sunflower & Castor & & \\
\hline Dry matter apparent digestibility & 0.67 & 0.68 & 0.69 & 0.69 & 0.009 & 0.954 \\
\hline Organic matter apparent digestibility & 0.69 & 0.69 & 0.70 & 0.70 & 0.008 & 0.954 \\
\hline Crude protein apparent digestibility & 0.71 & 0.72 & 0.74 & 0.74 & 0.008 & 0.788 \\
\hline Neutral detergent fiber digestibility & 0.52 & 0.52 & 0.52 & 0.55 & 0.001 & 0.906 \\
\hline Non-fiber carbohydrate apparent digestibility & 0.91 & 0.90 & 0.91 & 0.88 & 0.004 & 0.203 \\
\hline Ether extract apparent digestibility & $0.73 b$ & $0.84 \mathrm{a}$ & $0.83 \mathrm{a}$ & $0.81 \mathrm{a}$ & 0.009 & 0.012 \\
\hline Total digestible nutrients (g/kg DM) & 684.5 & 725.3 & 735.3 & 737.3 & 9.414 & 0.364 \\
\hline Total digestible nutrients $(\mathrm{kg} / \mathrm{d})$ & 0.85 & 0.97 & 0.97 & 1.04 & 0.044 & 0.254 \\
\hline Digestible energy (Mcal/kg DM) & 3.02 & 3.20 & 3.25 & 3.25 & 0.042 & 0.354 \\
\hline Digestible energy (Mcal/day) & 3.75 & 4.29 & 4.27 & 4.59 & 0.192 & 0.254 \\
\hline
\end{tabular}

DM - dry matter. 
Table 6 - Ruminal concentrations of SCFA $(\mathrm{mM})$ and ammonia nitrogen $(\mathrm{mg} / \mathrm{dL})$ by crossbred Dorper $\times$ Santa Inês sheep fed diets containing vegetable oils

\begin{tabular}{|c|c|c|c|c|c|c|c|c|}
\hline \multirow{2}{*}{ Variable } & \multicolumn{4}{|c|}{ Diets } & \multirow{2}{*}{$\begin{array}{c}\text { Standard error of } \\
\text { the mean }\end{array}$} & \multicolumn{3}{|c|}{ Effect $^{1}$} \\
\hline & Control & Canola & Sunflower & Castor & & Diet & Hour & Diet $\times$ Hour \\
\hline Acetate (mM) & $55.3 \mathrm{a}$ & $46.6 \mathrm{~b}$ & $43.3 \mathrm{~b}$ & $43.2 b$ & 0.97 & 0.006 & $<0.001$ & 0.798 \\
\hline Propionate (mM) & 15.8 & 15.2 & 15.9 & 13.5 & 0.34 & 0.548 & $<0.001$ & 0.070 \\
\hline Isobutyrate (mM) & 0.8 & 0.8 & 0.8 & 0.8 & 0.02 & 0.211 & $<0.001$ & 0.097 \\
\hline Butyrate (mM) & $8.2 \mathrm{a}$ & $5.8 \mathrm{~b}$ & $6.1 \mathrm{~b}$ & $5.3 b$ & 0.17 & 0.013 & 0.001 & 0.407 \\
\hline Isovalerate (mM) & 1.5 & 1.6 & 1.3 & 1.4 & 0.05 & 0.514 & $<0.001$ & 0.147 \\
\hline Valerate $(\mathrm{mM})$ & 0.9 & 0.8 & 0.8 & 0.8 & 0.02 & 0.745 & $<0.001$ & 0.216 \\
\hline $\mathrm{A}: \mathrm{P}$ & 3.6 & 3.1 & 2.8 & 3.2 & 0.05 & 0.182 & $<0.001$ & 0.114 \\
\hline Total SCFA (mM) & $82.4 \mathrm{a}$ & $70.8 \mathrm{~b}$ & $68.1 \mathrm{~b}$ & $65.0 \mathrm{~b}$ & 1.42 & 0.032 & $<0.001$ & 0.735 \\
\hline $\mathrm{pH}$ & 6.1 & 6.3 & 6.4 & 6.3 & 0.04 & 0.068 & $<0.001$ & 0.372 \\
\hline $\mathrm{N}-\mathrm{NH}_{3}$ & 17.3 & 16.5 & 15.3 & 17.4 & 0.65 & 0.781 & $<0.001$ & 0.365 \\
\hline
\end{tabular}

SCFA - short-chain fatty acid; A:P - acetate:propionate molar concentration ratio; $\mathrm{N}-\mathrm{NH}_{3}$ - ruminal concentration of ammonia $\mathrm{N}$. ${ }^{1} \mathrm{P}$-value

Although the fiber intake and digestibility (NDF) did not show difference $(\mathrm{P}>0.05)$ among the diets, there was a reduction of acetate concentration in the rumen. The seed digestion occurs at a higher rate than cellulose digestion (Russel \& Wilson, 1996) and probably higher than lipid digestion as well. In diets with oils, there was a lower amount of corn in the diet composition (approximately $10 \%$ ), which, in turn, caused reduction in the availability of substrate for fermentation in the rumen and therefore, resulted in decreased concentration of acetate and butyrate. Based on this theory, the molar concentration of propionate was also expected to be lower; however, lipid digestion in the rumen favors the production of free fatty acids (which were subjected to biohydrogenation) and glycerol, which, in turn, is converted into propionate (Chalupa et al., 1986).

The lower concentration of total SCFA in the rumen fluid $(\mathrm{P}<0.05)$ in the diets containing oil is due to the lower concentration of acetate and butyrate in these diets.

Shingfield et al. (2008) added different levels of linseed oil to the diet of lactating cows and reported reduction of acetate concentrations, even though SCFA values were not altered.

The average concentrations of isobutyrate and isovaleric and valeric acids and the relation between molar concentration of acetate and propionate were not changed $(\mathrm{P}>0.05)$ with the addition of canola, sunflower or castor oils.

The $\mathrm{pH}$ values in the rumen were not altered $(\mathrm{P}>0.05)$. In general, no changes of $\mathrm{pH}$ values in the rumen caused by lipid supplementation are reported in the literature (Athinkson et al., 2006; Beauchemin et al., 2007; Montgomery et al., 2008; Shingfield et al., 2008; Homem Junior et al., 2010).

However, in experiments with cattle, Vargas et al. (2002) reported increased of $\mathrm{pH}$ values in the rumen with the supplementation of soybeans and soybean oil and stated that this may occur when animals are fed lipids due to a possible reduction of DM intake and ruminal fermentation or reduction of dietary fiber degradation, which ultimately leads to a reduction of SCFA production and, thus, prevents the reduction of $\mathrm{pH}$ in the rumen. In a trial with sheep, Ivan et al. (2003) also observed an increase of $\mathrm{pH}$ in the rumen from 6.1 to 6.4 with the addition of $140 \mathrm{~g} / \mathrm{kg}$ of sunflower seeds to the diet.

Homem Junior et al. (2010), based on the study of Hightshoe et al. (1991), where the $\mathrm{pH}$ in the rumen was reduced with lipid supplementation using animal fat and increased when vegetable oils were used, stated that $\mathrm{pH}$ values are still highly related to the lipid source used.

The experimental diets did not affect the ruminal concentration of $\mathrm{N}^{-\mathrm{NH}_{3}}(\mathrm{P}>05)$, which was expected because the diets were formulated to be isonitrogenous and because no change was observed in DM intake.

Previous experiments with sheep rumen fluid showed results inconsistent with the study of sources of linoleic or linolenic acids (Gómez-Cortés et al., 2008; Zhang et al.,

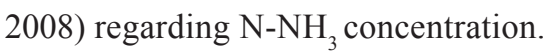

According to Mehrez et al. (1977) and Satter \& Slyter (1974), the maximum fermentative ruminal activity is obtained when $\mathrm{N}_{-} \mathrm{NH}_{3}$ reaches values between 5 and $23 \mathrm{mg} / \mathrm{dL}$. This suggests that, in the current study, there was no ammonia deficiency in the rumen fluid for the synthesis of microbial protein.

\section{Conclusions}

The supplementation of canola, sunflower or castor oils at $30 \mathrm{~g} / \mathrm{kg}$ in diets with $500 \mathrm{~g}$ roughage $/ \mathrm{kg}$ and $500 \mathrm{~g}$ concentrate $/ \mathrm{kg}$ does not affect nutrient intake and digestibility in sheep, despite reducing the concentration of short-chain fatty acids in the rumen. 


\section{References}

ASSOCIATION OF OFFICIAL ANALYTICAL CHEMISTS AOAC. Official methods of analysis. 19.ed. Washington, D.C., 2000. 1219p.

ATKINSON, R.L.; SCHOLLJEGERDES, E.J.; LAKE, S.L. et al. Esterified fatty acids in sheep fed a high-concentrate diet supplemented with Site and extent of digestion, duodenal flow, and intestinal disappearance of total and high-linoleate safflower oil. Journal of Animal Science, v.84, p.387-396, 2006.

BATEMAN, H.G.; JENKINS, T.C. Influence of soybean oil in high fiber diets fed to nonlactating cows on ruminal unsaturated fatty acids and nutrient digestibility. Journal of Dairy Science, v.81, p.2451-2458, 1998.

BEAUCHEMIN, K.A.; MCGINN, S.M.; PETIT, H.V. Methane abatement strategies for cattle: lipid supplementation of diets. Canadian Journal Animal Science, v.87, p.431-440, 2007.

CAMPOS, F.P.; NUSSIO, C.M.B.; NUSSIO, L.G. Métodos de análises de alimentos. Piracicaba: FEALQ, 2004. 135p.

CHALUPA, W.; VECCHIATELLI, B.; ESLER, A.E. Ruminal fermentation in vivo as influenced by long-chain fatty acids. Journal of Dairy Science, v.69, p.1293-1301, 1986.

CHANEY,A.L.; MARBACH, E.P. Modified reagents for determination for urea and ammonia. Clinical Chemistry, v.8, p.130-137, 1962.

COTTYN, B.G.; BOUCQUE, C.V. Rapid method for the gaschromatographic determination of volatile fatty acids in rumen fluid. Journal of Agricultural and Food Chemistry, v.16, p.105-107, 1968.

FILIPEK, J.; DVORAK, R. Determination of the volatile fatty acids content in the rumen liquid: comparison of gas-chromatography and capillary isotachophoresis. Acta Veterinaria Brno, v.78, p.637-633, 2009.

GÓMEZ-CORTÉS, P.; FRUTOS, P.; MANTECÓN, A.R. et al. Milk production, conjugated linoleic acid content, and in vitro ruminal fermentation in response to high levels of soybean oil in dairy ewe diet. Journal of Dairy Science, v.91, p. 1560-1569, 2008.

HALL, M.B. Calculation of non-structural carbohydrate content of feeds that contain non-protein nitrogen. University of Florida, 2000. p.A-25 (Bulletin 339).

HIGHTSHOE, R.B.; COCHRAN, R.C.; CORAH, L.R. et al. Effects of calcium soaps of fatty acids on postpartum reproductive function in beef cows. Journal of Animal Science, v.69, p.4097-4103, 1991.

HOLDEN, L.A. Comparison of methods of in vitro dry matter digestibility for ten feeds. Journal of Dairy Science, v.82, p.1791-1794, 1999.

HOMEM JUNIOR, A.C.; EZEQUIEL, J.M.B.; FÁVARO, V.R. et al. Fermentação ruminal de ovinos alimentados com alto concentrado e grãos de girassol ou gordura protegida. Arquivo Brasileiro de Medicina Veterinária e Zootecnia, v.62, p.144-153, 2010.

IVAN, M.; ENTZ, T.; MIR, P.S. et al. Effects of sunflower seed supplementation and different dietary protein concentrations on the ciliate protozoa population dynamics in the rumen of sheep. Canadian Journal of Animal Science, v.83, p.809-817, 2003.

JENKINS, T.C. Lipid metabolism in the rumen. Journal of Dairy Science, v.76, p.3851-3863, 1993.

KRAMER, J.K.G.; FELLNER, V.; DUGAN, M.E.R. et al. Evaluating acid and base catalysts in the methylation of milk and rumen fatty acids with special emphasis conjugated dieno and total trans fatty acids. Lipids, v.32, p.1219-1228, 1997.

MAIA, M.O.; QUEIROGA, R.C.R.E.; MEDEIROS, A.N. et al. Consumo, digestibilidade de nutrientes e parâmetros sanguíneos de cabras mestiças Moxotó suplementadas com óleos de licuri ou mamona. Revista Ciência Rural, v.40, p.149-155, 2010.
MATTOS, W.; PALMQUIST, D.L. increased polyunsaturated fatty acid yields in milk of cows fed protected fat. Journal of Dairy Science, v.57, p.1050-1054,1974.

MEHREZ, A.Z.; ORSKOV, E.R.; McDONALD, I. Rates of rumen fermentation in relation to ammonia concentration. British Journal of Nutrition, v.38, p.437-443, 1977.

MERTENS, D.R. Creating a system for meeting the fiber requirements of dairy cows. Journal of Dairy Science, v.80, p.1463-1481, 1997.

MONTGOMERY, S.P.; DROUILLARD, J.S.; NAGARAJA, T.G. et al. Effects of supplemental fat source on nutrient digestion and ruminal fermentation in steers. Journal of Animal Science, v.86, p.640-650, 2008.

MULLER, H.G. Introduccion a la reologia de los alimentos. Zaragoza: Editora Acribia, 1978. 174p.

NÖRNBERG, J.L.; STUMPF JÚNIOR, W.; LÓPEZ, J. et al. Valor do farelo de arroz integral como fonte de gordura na dieta de vacas jersey na fase inicial de lactação: digestibilidade aparente de nutrientes. Revista Brasileira de Zootecnia, v.33, p.2412-2421, 2004.

PALMQUIST, D.L.; GRIINARI, J.M. Milk fatty acid composition in response to reciprocal combinations of sunflower and fish oils in the diet. Animal Feed Science and Technology, v.131, p.358-369, 2006.

PALMQUIST, D.L.; JENKINS, T.C. Fat in lactation ration: review. Journal of Dairy Science, v.63, p.1-14, 1980.

PALMQUIST, D.L.; MATTOS, W.R.S. Metabolismo de lipídeos. In: BERCHIELLI, T.T.; PIRES, A.V.; OLIVEIRA, S.G. (Eds.) Nutrição de ruminantes. Jaboticabal: FUNEP, 2006. Cap.10, p.287-310.

RUSSELL, J.B.; WILSON, D.B. Why are ruminal cellulolytic bacteria unable to digest cellulose at low pH? Journal of Dairy Science, v.79, p.1503-1509, 1996.

SATTER, L.D.; SLYTER, L.L. Effect of ammonia concentration on rumen microbial protein production in vitro. British Journal of Nutrition, v.32, p.199-208, 1974.

SHINGFIELD, K.J.; AHVENJARVI, S.; TOIVONEN, V. et al. Effect of incremental levels of sunflower-seed oil in the diet on ruminal lipid metabolism in lactating cows. British Journal of Nutrition, v.99, p.971-983, 2008.

SHINGFIELD, K.J.; GRIINARI, J.M. Role of biohydrogenation intermediates in milk fat depression. European Journal of Lipid Science Technology, v.109, p.799-816, 2007.

SWIFT, R.W. The caloric value of TDN. Journal of Animal Science, v.16, p.753-756, 1957.

TORAL, P.G.; BELENGUER, A.; FRUTOS, P. et al. Effect of the supplementation of a high-concentrate diet with sunflower and fish oils on ruminal fermentation in sheep. Small Ruminant Research, v.81, p.119-125, 2009.

VAN SOEST, P.J.; ROBERTSON, J.B.; LEWIS, B.A. Methods for dietary fiber, neutral detergent fiber, and nonstarch polysaccharides in relation to animal nutrition. Journal of Dairy Science, v.74, p.3583-3597, 1991.

VARGAS, L.H.; LANA, R.P.; JHAM, G.N. et al. Adição de lipídios na ração de vacas leiteiras: parâmetros fermentativos ruminais, produção e composição do leite. Revista Brasileira de Zootecnia, v.31, p.522-529, 2002.

WEISS, W.P.; CONRAD, H.R.; ST.PIERRE, N.R. A theoreticallybased model for predicting total digestible nutrient values of forage and concentrates. Animal Feed Science and Technology, v.39, p.95-110, 1992.

WILES, P.G.; GRAY, I.K.; KISSLING, R.C. Routine analysis of proteins by Kjeldahl and Dumas methods: review and interlaboratory study using dairy products. Journal of AOAC International, v.81, p.620-632, 1998.

ZHANG, C.M.; GUO, Y.Q.; YUAN, Z.P. et al. Effect of octadeca carbon fatty acids on microbial fermentation, methanogenesis and microbial flora in vitro. Animal Feed Science and Technology, v.146, p.259-269, 2008. 